morally acceptable before 9 August, it must remain so-unless the moral fabric experienced a strange discontinuity on that day. If it did, moral philosophers may wish to note that, according to the U.S. Department of Health and Human Services, it occurred at 9 pm Eastern Standard Time.)

On the face of it, this concession should open the way for further experimentation down the road, as progress is made towards the understanding and use of the cells, both in the United States and in the other countries where many more stemcell lines will become available. The disease advocacy groups, with their influence in the U.S. Congress, seem to be particularly confident that the door is now ajar and can be opened further.

That said, an examination of the other side's perception of the debate suggests that this confidence could be misplaced. Like stem-cell research supporters, its opponents were at first unsure how to respond to Bush's 9 August announcement. Some groups, including the extremely conservative Family Research Council, took issue with the clear moral inference mentioned above, and denounced the decision. But the consensus of the larger religious groups opposed to embryonic stemcell research was to publicly accept the compromise.

Crucially, Bush quickly lent these groups sustenance by promising that his announcement had been final, and that he would veto any alteration to it. This promise, made a couple of days after Bush's televised broadcast, was highly significant: it captured the president's bottom line.

The announcement made on 9 August has flaws that will probably become even more glaring with the passage of time. Were there really 64 stem-cell lines extant on that date? How robust are they? How long will they last? Can these lines, co-cultured with mouse cells, ever be considered for use in human therapy? With his veto pledge, the president assured his closest supporters that these questions need not be answered, since his decision will not be revisited.

The U.S. Congress, led by Senators Edward Kennedy (Democrat, Massachusetts) and Arlen Specter (Republican, Pennsylvania), may hem and haw about the details of this decision, and indeed began doing so at a Senate hearing chaired by Senator Kennedy on 5 September. But stem-cell supporters would at present be hard put to muster a simple majority in the House and the Senate. They will never muster the two-thirds majority needed in both chambers to override President Bush's veto.

What all of this means is that there is unlikely to be any movement beyond the 64 stem cell lines during the 4 (or 8 ) years of Bush's presidency. For opponents of stem-cell research, that outcome represents a significant victory.

\title{
Declaring financial interests
}

Starting in October, the Nature titles, including Nature Genetics, will ask authors of research papers to declare any competing financial interests in their work (see Nature, 23 August, p. 751 for details). A short statement will appear in the published paper, and in cases where authors disclose a financial interest, details will be published on our web site. There is of course nothing wrong with commercialization per se; one reason for funding basic science research is the expectation that it will lead to usefuland potentially valuable-applications. The concern arises when such interests are undisclosed, raising the possibility of biasing effects that are invisible to the reader. There is evidence from the clinical literature that financial interests affect the reporting of research results, but there is little information about the basic science literature. We hope that by adopting a systematic approach to the disclosure of competing interests, we will enable our readers to make a more informed judgment of their possible significance. 